\title{
Linguistic change and social transformation
}

\author{
The spread of tuteo in Restoration Spain and the Second \\ Republic (1875-1939)
}

\begin{abstract}
This chapter investigates the spread of tuteo in a period of constant innovations which broke with hitherto apparently invulnerable social conventions. This spirit of innovation emerged at a particular moment in Spain's social and political history which was marked by far-reaching social upheavals: the Restoration (1875-1931), the Second Republic (1931-1936) and the Civil War (19361939). An analysis of an extensive corpus of private letters written between 1875 and 1939, expressing relations of friendship and affection, shows when and how changes occurred in the parameters of power and solidarity in dealings between interlocutors from the same social group and generation.
\end{abstract}

Keywords: Spanish sociolinguistics, linguistic and social change, tuteo in Spain, private letters corpus

\section{Introduction}

This chapter deals with the spread of tuteo, a wholesale linguistic change which affects the Spanish language's grammatical structure and gives linguistic codification to interpersonal relations. Tuteo is defined as the use of informal second person pronouns, e.g. tú, instead of polite pronouns, e.g. usted. Throughout the 20th century Spain stood out in the Hispanic world as a particularly innovative community in its use of pronouns to express politeness. This spirit of innovation emerged at a particular moment in Spain's social and political history which was marked by far-reaching social upheavals: the Restoration (1875-1931), the Second Republic (1931-1936), and the Civil War (1936-1939). The evolution of tú is explored during a historical period rife with innovations which broke with previous traditions.

Given such a complex period of change, the analysis follows the chronological order of the political and social events that had an impact on the pronoun system. The spread of innovation is considered over three distinct periods of Spanish history, in the course of which tuteo became the predominant form of address used in family relations and between friends and acquaintances of the same social status. These periods are: 
- 1800-1860: young aristocrats in Madrid initiated the expansion of tuteo (García Godoy 2008, 2010; Calderón 2010). The pronoun of solidarity, used first in family address among the upper classes, had spread to the middle classes by the middle of the 19th century.

- 1860-1930: the innovation spread across society at large, driven by the lower classes and by the intellectuals of the age, or "institutionists".

- 1930-1940: the decade's political events - the Second Republic (1931-1936) and the Civil War (1936-1939) - led to the definitive consolidation of the pronoun of solidarity in Spanish society.

In order to trace the evolution of this innovation in the society of the time, an extensive corpus of private letters written between 1875 and 1940 has been analysed. All the letters that express relations of friendship and affection show how and when the perception of power and solidarity in the relationships between interlocutors of the same social group and the same generation began to change.

The evolving uses of pronouns among the lower classes are studied with the aid of a corpus containing letters from Asturians (López Álvarez 2000; Martinez Martín 2010) and Galicians (Soutelo 2003) who departed for the Americas as economic emigrants in the second half of the 19th century and the early decades of the 20th century. This collection of letters makes it clear how mutual use of tuteo developed over a lengthy period of time and makes it possible to explore how personal changes were being transformed at the start of the last century.

Secondly, the corpus reveals patterns of use among the better educated, the products of the movement of social renewal triggered by Spain's Free Educational Institutions of the period and their promoters, the "institutionists". Such letters are more easily available given the political and social prominence of their authors. The present study reviews the correspondence between a selection of interrelated intellectuals (Altolaguirre 2005; Anderson \& Maurer 1997; Castillejo 1999; Cortés \& García Perales 2009; Menéndez y Pelayo \& Leopoldo Alas 1943).

The pattern of innovation traced in this study comes to a climax in the 1930s, the decade of the Second Republic and the Civil War. Most recent research into this period has uncovered important collections of letters written by Republican (Hinojosa 2009; Matthews 2015; Sierra 2008) and Francoist (Ramón \& Ortiz 2003) soldiers during the war, as well as by the Republican prisoners (Fonseca 2014; Martínez Aguirre 2014; Sierra 2003) who would fill Spain's prisons from the outset of the Franco dictatorship. The analysis of these letters from the 1930s yields important evidence about linguistic change in Spain during the period.

In short, the aim of what follows is to reconstruct the historical context that enabled the spread of tuteo: the social conditions which facilitated it, the means by which it was propagated through the social fabric of Spain at the time, and 
the confluence of interests between different social sectors which encouraged the evolution of the system of solidarity.

\section{1800-1860: the development of tuteo in the 19th century, a linguistic change from above}

Available data (García Godoy 2008, 2010; Calderón Campos 2010) about the appearance of tuteo in horizontal relations, that is, between equals, situates this pronominal change in aristocratic circles of the early 19th century. With a view to making the analysis clearer, we separate the spread of tuteo in the family from its spread in horizontal relations between friends and acquaintances. Tuteo as addressed to one or other of these two groups had different social consequences which need to be viewed as catalysts of its diffusion in Spain in the early decades of the 20th century.

The tuteo of parents by offspring in place of a previous non-reciprocal ustedeo, ${ }^{1}$ was the most significant change in the pronominal system in the early 19 th century; by the end of the century the use of tú in imitation of high society was starting to be widespread among the younger generations of the middle class:

Addressing parents as tú was a distinguishing feature of high society. This glamorous formula began to become more widespread in Restoration Spain, when the new pattern starts to be the preferred form among Madrid's urban, middle-class young people, who were under 20 in 1890.

(García Godoy 2010: 603)

According to García Godoy (2010: 613), "the new elocutional pattern amounts to a change from above, initiated by the aristocratic classes and imitated intentionally by the affluent upper-middle classes". Women "under 35 from the middle and upper levels of the urban bourgeoisie" were responsible for the change and the epicentre of the innovation was Madrid, which was more advanced than Andalusia, where modes of address were slower to develop than in the cities.

As for relations outside the family between friends and acqaintances from the same social class, it was the younger generation with high economic status and aristocratic tastes - the so-called pollería 'gathering of young people, chickens' - which made tuteo fashionable. García Godoy (2008: 44) explains the main traits of the lechuguino 'dandy', the archetypal member of this social group, with

1 Ustedeo means use of $u$ sted. 
reference to a sketch published in the Madrileñian weekly periodical, Semanario Pintoresco, with the title Spanish types. The enthusiast: ${ }^{2}$

\begin{abstract}
El aficionado moderno es un hijo maleducado [...] apunta en la cartera el nombre del último sastre que ha llegado de París [...] prefiere las telas impermeables al paraguas. Reprueba el $\mathrm{V}^{3}$. de buenas a primeras porque entre personas que se encuentran, como él dice a una misma altura, es una palabra muy fraternal ese tú que forma el encanto y la delicadeza de los enamorados.

(Semanario pintoresco 1846: 404)

'The modern enthusiast is a spoilt child [...] [who] jots down the name of the latest tailor to have arrived from Paris [...] prefers waterproof cloths to umbrellas. They quite simply scoff at usted because when people of, so to speak, the same standing meet, this tú is a very fraternal word which gives form to the charm and delicacy of the lovestruck.'
\end{abstract}

García Godoy concludes her explanation by also highlighting the role of women as prime movers of the innovation, as may be deduced from the courtesy manuals which "reprove the fashion for tuteo in Restoration Spain, and point to young upper-class women as the main exponents of the change" (García Godoy 2008: 46).

Mutual tuteo $(\mathrm{T} \leftrightarrow \mathrm{T})$ among the upper classes implied class solidarity and peer complicity, while also marking a separation from the rest of society, with which the old assymetrical system of hierarchical address was maintained: $\mathrm{V}$ (usted(es)) for the superior, $\mathrm{T}$ (tú/vosotros) for the inferior.

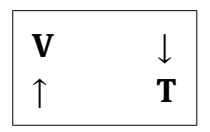

The familiar and the aristocratic forms of tuteo were motivated by different social conditioning factors. The family was the basic unit of society which presupposed ties of solidarity. However, this solidarity was projected onto a hierarchical structure which only admitted the innovation gradually: tuteo first began to be used among relatives of the same generation (siblings, cousins, siblings-in-law), while the tuteo of parents by young aristocrats became fashionable later. By promoting affection over respect, the relations between parents and children were transformed in a way that created a space for affective proximity in pre-existing relationships of solidarity, but without eliminating any social barriers.

2 In the citations, all forms of address and sociolinguistic comments referring to forms of address are in italics. The emphasis is always the author's.

$3 \mathrm{~V}$ stands for usted(es) and T for tú/vosotros. 


\section{1860-1930: urban development, modernity and political evolution}

The new century ushered in an acceleration in the transformation of 19th-century modes of address. This was a reflection of social changes: migrations from the country to the towns and cities, a fall in illiteracy rates, a second phase of industrialisation, the growth of the third sector in the economy, the consolidation of political parties and trade unions representing the masses, and the rise in living standards (Otero 2015: 18).

This social development was founded on the metropolitisation of cities such as Madrid, Barcelona and Bilbao. The steps towards modernity taken by Madrid in the 1930s led to levels of progress comparable to those of other European capitals of the age. Spatial expansion and demographic growth altered the period's economic, political, social and cultural coordinates and fostered the emergence of the new urban middle classes composed of professionals, tradesmen, salaried and qualified workers whose standards of living, habits of consumption and leisure, system of values and social practices signalled the arrival of modernity. The new century saw how the parties of the masses came to take centre stage (Otero 2015: 16).

\subsection{Tuteo popular: a change from below. The letters of Asturian and Galician emigrants}

In order to identify the use of pronouns among the lower classes, we have analysed three corpora of letters written by Asturian and Galician emigrants to America, where they hoped to improve their economic condition. The letters written by the Asturian emigrants and contained in two letter collections span a broad period of time: the letters of the first collection were written between 1863-1936 (Martínez Martin 2010), and those of the second between 1864-1925 (López Álvarez 2000). For their part, the corpus of letters written by Galician emigrants covers only the decade of the 1930s (Soutelo Vázquez 2003). From the three collections a total of 105 letters involving 210 different interlocutors have been analysed.

The letters studied still retain a traditional letter structure, with fixed greetings (mi estimado amigo, mi buen amigo, queridos padres 'my dear friend, my good friend, dear parents' and farewells). The greetings are always followed by a paragraph enquiring after the health of the interlocutor or relative by means of conventional formulas, as illustrated in examples (1) to (9). 
(1) [tuteo]

Estimado hermano: desearé que al recibo de ésta te encuentres con saluz [sic] en compañía de nuestros padres y hermanos, pues la mía y la de todos es buena, a D[ios] g[raci]as./Hermano, he recibido tu apreciable y deseada carta con fecha del 16 de agosto y en ella veo el buen estado de saluz [sic] [...]" (Letter from Luis Carrera (Silao, México) to his brother José Carrera (Posada, Llanes), 12.10.1888)

'Dear brother: I hope that you are well when you get this, along with our parents and the rest of the family, just as I'm well and so is everybody else, thank God./Brother, I received your [tu] kind and eagerly awaited card dated 16th August, and I can see from that you're well [...]'

(2) [tuteo]

Mi estimado amigo: la presente tiene por objeto el participarte que lo mismo Fabián que yo tenemos pensado embarcar el 21 ó 22 del prósimo [sic] noviembre en La Coruña, vien [sic] en el Correo o en el Francés, es decir, si el Correo lleva mucha tropa iremos en el Francés, según veamos haremos [...]" (Letter from Aurelio Arango (Cañedo, Pravia) to his friend Indalecio del Río (La Habana, Cuba), 30.10.1895)

'My dear friend: This is to let you know that Fabian and I are both thinking of embarking next 21 or 22 November in La Coruña, either on El Correo or on El Francés, I mean, if El Correo is too crowded we'll go on El Francés, it all depends [...]'

(3) [usted]

Querido padre: me alegro que al recibo de ésta se halle vueno [sic] en compañía de nuestra madre y hermanos [...] Querido padre, la presente es para manifestarle que le mando el viaje para mi hermano [...]" (Letter from José Fernández (Buenos Aires) to his father Ramón Fernández (Villamar de Abajo, Salas), 18.8.1909)

'Dear father: I hope you're well, along with mother and the rest of the family, when you receive this [...] Dear father, this is to tell you that I'm sending you the ticket for my brother [...]'

(4) [tuteo]

Querido amigo: tengo en mi poder tu estimada carta y por ella beo [sic] que estás bueno, yo sin nobedaz [sic]./Pues Manuel, refiriendo acerca de 
lo que tú mi [sic] dices de que tú tienes miedo binir [sic] para aquí porque tienes miedo hir [sic] para Triscornia, pues chico sobre ese particular no tengas miedo porque para eso estoy yo aquí [...] (Letter from Amado García (La Habana) to his friend Manuel Suárez Roza (Cancienes, Corvera de Asturias), 17.12.1919)

'Dear friend: I've got your kind letter here and I see that you're well. No news for my part./Anyway Manuel, about what you say about being afraid to come here because you're afraid to go by way of Triscornia, well, mate, there's no need to be afraid about that because that's what I'm here for [...]'

(5) [usted]

Mi querida mamá:/Deseo que al recibo de ésta se allen [sic] disfrutando de buena salud, yo bien a Dios gracias./Sabrán como llegamos a ésta sin novedad el jueves por la mañana y desembarcamos a la tarde [...] (Letter from Ricardo Ruiz Balbín (Ciego de Ávila, Cuba) to his mother Bernarda Ruiz Balbín (Lué, Colunga), 13.12.1920)

'My dear mama:/I hope this find you all in good health. I'm well, thank God./ Just to let you know that we arrive safely on Thursday morning and disembark in the afternoon [...]'

(6) [tuteo]

Mi inolvidable Alfredo:/Para que en ningún concepto tengas tú mucho a decir que notas en mí cierta indiferencia te escribiré muy extenso y bastante frecuente [...] (Letter from Antonia M. Abrahantes (Colonia La Florida, Cuba) to her boyfriend Alfredo Rodríguez (Cuba), 20.11.1923)

'My unforgettable Alfredo:/So that you don't have the slightest reason to say that I seem a bit indifferent, I'll write to you at length and quite often [...]'

(7) [tuteo]

Amor mío:/Prometí escribirte y así lo cumplo, quizás impulsada tal vez por causas que yo misma no sé explicarme, como no tengo la seguridad que tú vengas el jueves según son mis deseos [...] (Letter from Ana Mâ Cruz (Peñasco, Cuba) to her boyfriend José Manuel Rodríguez (Cruces, Cuba), 15.12.1930)

'My dear:/I promised to write to you and I'm keeping my promise, perhaps driven by reasons that not even I can explain, as I'm not sure you'll come on Thursday, as it is my wish [...]' 
(8) [tuteo]

Mi más querida amiga: hace días reciví [sic] tu atenta carta la que me llenó de satisfacción y por ser tú la más íntima amiga y que con más gusto me pones al corriente de todo lo de por hay [sic] [...] (Letter from Honorina (Caibarien, Cuba) to her friend Domitila Rodríguez (Inclán, Pravia), 15.12.1924)

'My dearest friend: I got your kind letter some days ago and I really liked it, and as you're the closest friend and you take pleasure in keeping me up to date with everything that's going on there [...]'

(9) [tuteo]

Mi buen amigo Herminio: poseo tu carta fecha 5 y seis días antes de las elecciones de ésa de lo cual ya te felicité por el triunfo alcanzado en ellas, y hoy te felicito a $t i$ y al amigo Riestra como así mismo a los amigos Arizaya, Ramonín y demás por el advenimiento de la República consagrada a un nuevo régimen de gobierno [...] (Letter from Bernardo Antuña (Tenafly, New Jersey) to his friend Herminio Fernández (Noreña, Gijón), 27.4.1931)

'My dear friend Herminio: I am in receipt of your letter of the 5th, six days before the elections on your success for which I already congratulated you, and today I congratulate you and friend Riestra as well as friends Arizaya, Ramonín and the rest for the advent of the Republic, committed to a new governmental regime [...]'

Table 1 shows that in $73 \%$ of the letters studied the emigrants used tuteo, whereas $27 \%$ used usted: this means that between the later 19th and the early 20th centuries, tuteo was firmly established among this social grouping in horizontal relationships between siblings, cousins or brothers/sisters-in-law, as well as in the egalitarian address between friends, partners and acquaintances of both sexes.

Table 1: Pronominal use in emigrant letters (1860-1930). T= tú; V = usted.

\begin{tabular}{lllllllll}
\hline & \multicolumn{3}{c}{ Family relationships } & & & Non-family relationships & Total \\
\cline { 2 - 3 } & $\begin{array}{l}\text { Offspring } \\
\text { to parents }\end{array}$ & $\begin{array}{l}\text { Father/ } \\
\text { mother to } \\
\text { offspring }\end{array}$ & $\begin{array}{l}\text { Siblings, } \\
\text { cousins }\end{array}$ & $\begin{array}{l}\text { Brothers/ } \\
\text { sisters- } \\
\text { in-law }\end{array}$ & Friends & Acquaintances & \\
\hline usted & $22 \mathrm{~V}$ & & $2 \mathrm{~V}$ & $1 \mathrm{~V}$ & $2 \mathrm{~V}$ & $1 \mathrm{~V}$ & $28 \mathrm{~V}(27 \%)$ \\
\hline tú & $2 \mathrm{~T}$ & $6 \mathrm{~T}$ & $42 \mathrm{~T}$ & $6 \mathrm{~T}$ & $21 \mathrm{~T}$ & & $77 \mathrm{~T}(73 \%)$ \\
\hline
\end{tabular}

The emigrants' correspondence reveals how intensively tuteo was propagated in relations between equals. The bulk of the correspondence written between 
1860 and 1900 was between relatives, but some was also addressed to friends, which demonstrates that tuteo was already habitual in horizontal non-family relationships (21 instances of tú against three of usted). In contrast, for addressing parents or other members of the family in a position of hierarchical superiority (aunts and uncles, grandparents), it was only later that tuteo came to be employed (22 instances of usted and only two of tú), and this was usually after tuteo had defined the egalitarian address between friends and acquaintances. It was, therefore, frequent for Asturian emigrants to use tuteo to address their friends, while continuing to favour usted for fathers, mothers and grandparents.

Except for parents addressing offspring or acquaintances, in all the cases reflected in the table the two pronouns tú and usted co-exist side by side. This alternation between two forms as co-variants when addressing the same type of interlocutor indicates a change in progress from below where tuteo, present in $73 \%$ of the letters analysed, has taken over as the first-choice option.

\subsection{The Free Educational Institution (FEI) and the reformist project of the Second Republic: The Silver Age of Spanish science and culture}

In the vanguard of these currents of renewal, the so-called "institutionists" played a key role in the social transformation which characterised turn-of-thecentury Spain. Since the foundation in 1876 of the Free Educational Institution (Institución Libre de Enseñanza), and until its demise in 1936, intellectuals on the national political scene took up the cause of liberal and progressive ideals. With the freedom of education and science as its banner, the FEI inspired moves to open the university to society (Moreno \& Martínez 2012, I: 18-19). For the institutionists, if the breach separating Spain from the most advanced European nations was to be closed, the education system had to be reformed, an opinion that was to become part of the creed of the reformist intelligentsia during the first three decades of the 20th century (Otero 2014).

In harmony with institutionist principles, in 1907 the Junta de Ampliación de Estudios 'Council for Advanced Studies' came into being, the brainchild of Francisco Giner de los Ríos, whose goal was to modernise education and scientific research in Spain (Otero 2014). ${ }^{4}$ The leading scientists of the age were asso-

4 The Council created the Centre for Historical Studies and the National Institute of Physical and Natural Sciences. The former organised the Humanities into sections such as Philology, under the direction of Ramón Menéndez Pidal, and History, directed by leading lights like Claudio Sánchez-Albornoz or Américo Castro (Otero 2014). 
ciated with the Council while at the same time holding university chairs, most of them in the Central University of Madrid. A generation of young researchers was nurtured around them, researchers who had been trained abroad thanks to the grants scheme before joining scientific institutions. With the proclamation of the Second Republic in April 1931, the Council's activities were given a new boost and university access was opened to the newly emergent middle classes.

The forging of this alliance between science and politics during the Second Republic permitted the development of the schemes to renew education which the Free Educational Institution and the reformist sectors had been campaigning for since the turn of the century. If the nation, whose illiteracy rates were high, was to be regenerated, its education had to be revamped and universalised (Otero 2015: 33, 35). The Council's achievements during the barely thirty years of its brief existence amounted to a genuine Silver Age of Spanish science, the fulfilment of a dream which, like the modernising project as a whole, would be cut short by the Civil War.

\subsubsection{The usted of the institutionists (first generation)}

The forms of address favoured by the institutionists, an educated bourgeoisie composed of leading social, political or cultural figures, may be determined by reviewing countless letter collections. For our study we selected the correspondence between 33 interlocutors belonging to the social circle of the institutionists (Altolaguirre 2005; Anderson \& Maurer 1997; Castillejo 1999; Cortés y García Perales 2009).

The first generation of institutionists includes intellectuals such as Giner de los Ríos, Ramón y Cajal, Ramón Menéndez Pidal, Manuel Bartolomé Cossio, Juan Ramón Jiménez, Antonio Machado, Américo Castro, María de Maeztu, Navarro Tomás, Ortega y Gasset among many others. They were the teachers of the second generation (1890-1910), who had already received training under the modernising aegis of the Council for Advanced Studies.

In their correspondence, the intellectuals born before 1890 preserve usted despite the affectionate relations that may often be read into their letters. This is because for the generation of Menéndez Pidal and Antonio Machado forms of politeness and respect were too deeply rooted in their conception of personal relationships. It is striking that even Américo Castro, Juan Ramón Jiménez, María de Maeztu or Navarro Tomás, all of whom were in their forties and therefore relatively young at the start of the Second Republic, never depart from using usted to address colleagues or friends, regardless of their ages, as can be seen in examples (10 to (18). 
(10) [usted]

Sr. D. Leopoldo Alas/Mi querido amigo: Perdone Vd. que hasta hoy haya dilatado el contestar a su muy grata, pero de fijo me ha de disculpar usted si recuerda las mil molestias y pesadeces de esta vida que llaman política, a la cual mis pecados me han traído, aunque sea por accidente [...] (Letter from Marcelino Menéndez y Pelayo to Leopoldo Alas “Clarín” (Madrid), 23.2.1885)

'Leopoldo Alas, Esq./My dear friend: please forgive me for not having taken time until today to reply to your kind letter, but I'm sure you'll pardon me once you recall the thousands of trials and tribulations associated with what they call a life in politics, a life to which my sins have brought me, albeit by accident [...]'

(11) [usted $]$

Mi querido amigo y condiscípulo: Acabo ahora mismo de leer con muchísimo gusto y provecho, su prólogo de la Proaladia, y le doy por él las gracias y la enhorabuena [...] (Letter from Leopoldo Alas “Clarín” to Marcelino Menéndez y Pelayo (Madrid), 23.3.1900)

'My dear friend and co-student: I've just read with the utmost pleasure and benefit your prologue to Proaladia, for which I thank and congratulate you [...]'

(12) [usted]

Mi distinguido amigo: Recibí la suya a la que no he contestado antes por quererlo hacer a Madrid y cuando hubiera $V$. reanudado sus trabajos [...] (Letter from Elvira Alonso to José Castillejo (Paris), 14.8.1907)

'My distinguished friend: I haven't replied to your latest since I wished to write to you in Madrid, and once you had returned to work [...]'

(13) [usted $]$

Querido Cossio: Recibiría Vd. la mía de ayer. Ya se figurará lo que damos vuelta a su asunto: D. Francisco, Posada, Azcárate, Uña y yo [...] (Letter from José Castillejo to M. B. Cossío (London), 28.1.1908)

'Dear Cossío: You must have received my letter of yesterday. You'll already be able to imagine all the thought we're giving to your affair: D. Francisco, Posada, Azcárate, Uña and I [...]' 
(14) [usted]

Sr. D. Miguel de Unamuno/Mi querido amigo y compañero: mucho hubiera querido que durante mi estancia ahí hubiésemos hablado algo, ya que hace tanto tiempo que no tenía ese gusto, y que éste hubiese sido mayor siendo nuestras conversaciones dentro de esa ciudad que $V d$. ha hecho su segunda patria. Ojalá podamos vernos en otra ocasión por acá [...] (Letter from Ramón Menéndez Pidal to Miguel de Unamuno (Madrid), 9.10.1910).

'Miguel de Unamuno, Esq./My dear friend and colleague: I would dearly like to have conversed with you during my stay since I haven't had the pleasure for such a long time, and the pleasure would have been all the greater for our conversations taking place in that city which you have made your second home. I hope we can meet up another time over here [...]'

(15) [usted]

Querido D. Ramón: Llegó la carta de $V$. y se me admitió a trabajar en el Laboratorio. He encontrado además una pensión buena y barata. Estoy, pues, en buenas circunstancias para poder aprovechar aquí un poco el tiempo./El Laboratorio me ha dejado admirado; hay en él todo lo que se puede desear, todos los aparatos de física, de medicina y puramente de fonética que suelen emplearse en este estudio. La instalación de muebles, electricidad, gas, agua, etc., está hecha con un gran sentido práctico y además con una riqueza casi suntuosa [...] (Letter from Tomás Navarro Tomás to Ramón Menéndez Pidal (Hamburg), 4.8.1913)

'Dear D. Ramón: Your letter arrived and I was admitted to work in the laboratory. I've also found a decent and cheap boarding house. I am, then, well set to be able to make something of my time here./The laboratory impressed me; it has all one could wish for, all the apparatus for physics, medicine and pure phonetics that are normally employed in this field of study. The furnishings, electricity, gas, water, etc. have all been fitted with good practical sense and almost to the point of luxury [...]'

(16) [usted $]$

Sr. Don Ramón Menéndez Pidal/Muy Sr. mío y apreciado amigo: Aprovecho el viaje de mi amigo Mosén Llauró para escribirle dos palabras. En primer lugar para felicitarle por haber sido propuesto para la presidencia de la Société de Linguistique Romane [...] (Letter from Antoni Griera to Ramón Menéndez Pidal (Barcelona), October 1927) 
'Ramón Menéndez Pidal, Esq./My dear Sir and valued friend: I take the opportunity presented by the journey of my friend Mosén Llauró to write you a couple of words. Firstly, to congratulate you on being nominated to the presidency of the Société de Linguistique Romane [...]'

(17) [usted $]$

Querido Alonso: [...] Del Atlas Lingüístico hay una esperanza de empezar, pero sólo una esperanza. La ausencia de usted es irreparable. Estoy haciendo un cursillo de preparación fonética para tres jóvenes que parecen dispuestos a viajar; no sé si usted les conocerá: Lapesa, Lacalle y Ortega Lamadrid. El primero es el mejor. El Ministerio de Estado nos ha dado 5.000 pesetas para los primeros viajes. Tal vez hagamos unas salidas de tanteo esta primavera [...] (Letter from Tomás Navarro Tomás to Amado Alonso (Madrid), 2.3.1929)

'Dear Alonso: [...] À propos the Atlas Lingüístico, there's a chance, but only a slim one, that work may commence. There is no brooking your absence. I'm running a small course in phonetic training for three young men who seem willing to travel; I don't know if you know them: Lapesa, Lacalle and Ortega Lamadrid. The first is the best. The Ministry of State has given us 5,000 pesetas for the first trips. We may do some reconnoitring this spring [...]'

(18) [usted $]$

Sr. D. Felipe Gil Casares/Rector de la Universidad de Santiago/Mi distinguido amigo y compañero: me entero aquí casualmente de que fue entregado en la frontera a las autoridades de Tuy por la policía portuguesa el Sr. Otero [...] Yo, invocando la buena amistad que me une al primo de $V$. D. José Casares Gil, acudo a Vd. rogándole intervenga, si lo cree oportuno, para librar a un inocente y salvar un trabajo de alto interés para la cultura y la historia españolas [...] (Letter from Menéndez Pidal to F. Gil Casares (La Habana), 18.2.1937)

'D. Felipe Gil Casares, Esq./Rector of the University of Santiago/My distinguished friend and colleague: I happen to have been informed here that the Portuguese police delivered Mr Otero over at the border to the Tuy authorities [...] May I appeal to the close friendship that connects me to your cousin, José Casares Gil, and ask you to intervene, should you think it opportune, to free an innocent man and to salvage a work of great interest for Spanish history and culture?' 
In turn, and in reciprocation, in this generation the senders are always addressed as usted by all their interlocutors, regardless of status, age or gender.

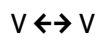

The nominal forms employed in letters also kept a respectful distance: señor don + NP and surname (Sr. Don Ramón Menéndez Pidal; Sr. D. Miguel de Unamuno); don + NP (Querido D. Ramón); surname (Querido Alonso; Querido Cossío). The usted address in the letters was established from the outset of the relationship and remains unchanged thereafter. It comes as something of a surprise to see how these intellectuals, many of whom lived well into their nineties and wrote hundreds of letters, preserved the 19th-century system of address throughout the 20th century.

An analysis of this group's letters provides evidence of a generational gap separating those born between 1860 and 1890 (first generation), and their disciples, born around the turn of the century, between 1890 and 1910 (second generation). In relations with their peers, the first generation institutionists always addressed their interlocutors as usted, regardless of age or sex (see Table 2). This respectful form of address was unaltered by the degree of personal affection;

Table 2: First generation institutionists (1850-1889).

\begin{tabular}{lll}
\hline \multicolumn{3}{c}{ First Generation Institutionists, born between 1850-1889 } \\
PRONOMINAL ADDRESS: \\
V $\leftrightarrow$ V (with all interlocutors)
\end{tabular}


rather, it was the custom to address teacher, disciple, colleague, acquaintance and friend as usted. In this generation, the pronouns used in address show no variation: quite categorically, usted is the form to be employed, which leads to the conclusion that the intellectuals of the 19th century never adapted to the change in egalitarian, non-family relations.

\subsubsection{Spread of tuteo popular among institutionists (second generation)}

This second group of institutionists also comprised some of the leading scientists, thinkers, writers, teachers, artists or philologists of the period, such as Dámaso Alonso, Gerardo Diego, Jorge Guillén, Rafael Lapesa, Federico García Lorca, Miguel Hernández, María Zambrano, Rafael Alberti, Lorenzo Rodríguez Castellano, Aurelio M. Espinosa, Vicente Aleixandre, Amado Alonso and many others. It is a generation which came of age under the Second Republic: in 1930 its members were all aged between twenty and thirty, while in the same year the ages of their mentors, the instituionists of the first generation, ranged from 40 to 70. Table 3 shows the names of some representants of this second generation whose letters have been analysed.

Table 3: Second generation institutionists (1890-1910).

\begin{tabular}{|c|c|}
\hline \multicolumn{2}{|c|}{$\begin{array}{l}\text { Second Generation: Born between 1890-1910 } \\
\text { PRONOMINAL ADDRESS: } \\
\mathrm{T} \leftrightarrow \mathrm{T} \text { (with own generation) } \\
\mathrm{V} \leftrightarrow \mathrm{V} \text { (with their elders) }\end{array}$} \\
\hline $\begin{array}{l}\text { Born in the } 1890 \mathrm{~s} \\
\text { In their } 30 \mathrm{~s} \text { in } 1930 \mathrm{~s}\end{array}$ & $\begin{array}{l}\text { Born in the } 1900 \mathrm{~s} \\
\text { In their } 20 \mathrm{~s} \text { in } 1930 \mathrm{~s}\end{array}$ \\
\hline $\begin{array}{l}\text { Dámaso Alonso (1898-1990) } \\
\text { Amado Alonso (1896-1952) } \\
\text { Federico García Lorca (1898-1936) } \\
\text { Vicente Aleixandre (1898-1984) } \\
\text { Gerardo Diego (1896-1987) } \\
\text { Jorge Guillén (1893-1984) }\end{array}$ & $\begin{array}{l}\text { Rafael Lapesa (1908-2001) } \\
\text { Aurelio M. Espinosa (1907-2004) } \\
\text { Lorenzo Rodríguez Castellano (1905-1986) } \\
\text { M. Sanchis Guarner (1911-1981) } \\
\text { Aníbal Otero (1911-1974) } \\
\text { Miguel Hernández (1910-1942) } \\
\text { Salvador Dalí (1904-1989) } \\
\text { Manuel Altolaguirre (1905-1959) } \\
\text { Luis Cernuda (1902-1963) } \\
\text { María Zambrano (1904-1991) } \\
\text { Rafael Alberti (1902-1999) }\end{array}$ \\
\hline
\end{tabular}


While the letter collections offer a conservative picture of the 19th-century institutionists, with the new century the convergence of cultural elites and lower classes became increasingly evident: the generation that enrolled in Madrid's university in the 1920s and 1930s adopted tuteo to address companions, colleagues, friends and acquaintances of the same age and of both sexes. Some of the period's major figures offer testimony to the new uses. Lapesa (1996: 357) explains how, in the early 20th century:

En el trato familiar se había aflojado ya la respetuosa rigidez en la relación entre padres e hijos: el galicismo papá y mamá y el tuteo entre padres e hijos se habían generalizado en los estratos sociales alto y medio, mientras el padre y madre y el usted, ustedes de hijos a progenitores se mantenían en los ambientes populares y rústicos [...]. El tratamiento recíproco de usted entre jóvenes fue disminuyendo: si en 1923-1925 podía darse todavía entre varones compañeros de estudios o de oficina, en los años treinta el tuteo se había impuesto incluso entre ambos sexos.

(Lapesa 1996: 357)

'Address within the family had by now loosened the relationship of stiff respect between parents and offspring: the gallicisms papá and mamá and tuteo between parents and offspring had spread throughout the middle and upper social strata, while the use of padre and madre and usted or ustedes between offspring and parents was retained in lower and rural spheres [...] The reciprocal use of usted between young people was in decline: if between 1923-1925 it could still be heard among male fellow students and officeworkers, by the 1930s tuteo had won the day even between members of both sexes.'

Those born around the turn of the century continued to use usted to address colleagues, acquaintances and friends from the previous generation $(\mathrm{V} \leftrightarrow \mathrm{V})$, but had already adopted tuteo for friends and acquaintances of their own age or younger $(\mathrm{T} \leftrightarrow \mathrm{T})$. The nominal forms in their letters exhibit the same pattern of reciprocal respect towards elders but of solidarity with members of their own generation. When addressing their seniors, the younger institutionists used such formulas of respect such as: don + NP (don Ramón); señor 'Mr' + surname (e.g. Sr. Navarro); distinguido profesor 'distinguished professor'; muy distinguido señor mío 'my most distinguished Sir'. In contrast, they used surname or forename to address those of the same age or younger. And this is due precisely to the second generation, students at Madrid's Central University in the 1920s and 1930s where they were educated based on Krausist ${ }^{5}$ ideals which combined quality training with social awareness. For they set the seal on tuteo popular which was being propagated by the lower classes. When using tuteo amongst themselves, the

5 Krausism is a doctrine which defended quality training and academic freedom against dogmatism. It takes its name from Karl Christian Friedrich Kraus. His philosophy was spread in Spain by Julián Sanz del Río and the Institución Libre de Enseñanza (Free Educational Institution). 
young university students were not trying to emulate the fashion of the young 19th-century aristocrats, but were adopting the form of address that had taken root among the lower classes whose interests the enlightened bourgeoisie had made their own. By adopting tuteo in this way, the intellectuals were instrumental in the final dismantling of the 19th-century system of address; for in the first three decades of the 20th century, Spain underwent root and branch social transformation, whose catalysts included a Republic and a Civil War.

Before the war, Dámaso Alonso recalled how tuteo between peers - whether in age, gender or social class - had caught on in the university classrooms of the 1920s:

ya por aquellos años de antes de 1936 eran evidentes los avances del tuteo. La juventud de ambos sexos lo admite como una de las formas naturales de su concepción de vida. Otras causas, no políticas, van a colaborar [...]

(Dámaso Alonso 1962: 264)

'the onward march of tuteo was apparent even in the years before 1936. Young people of both sexes accepted it as one of the natural forms their view of life took. Other, non-political causes played a part [...]'

This process accelerated throughout the 1920s, was propagated across society under the Second Republic, and was consolidated during the war. The young institutionists adopted tuteo popular with enthusiasm, but only when addressing other young people. When addressing their seniors or teachers, with whom they were often united in friendship or by father-son relationships, they still preserved reciprocal usted, which the former insisted on in all non-family relations.

Examples (19) to (21) from letters written by students to their teachers illustrate reciprocal usted $(\mathrm{V} \leftarrow \mathrm{V})$ between institutionists from different generations.

[usted]

Querido Sr. Navarro: Diversas circunstancias han retrasado considerablemente el envío de noticias nuestras. Las distancias entre punto y punto han resultado grandes, y por consiguiente hemos tenido poco tiempo para escribir [...] Recuerdos a Vallelado y Aguilera, y a Ud. le aprecian siempre/Aurelio Espinosa y L. Rodríguez (Letter from A. M. Espinosa and L. Rodríguez Castellano to Tomás Navarro Tomás (Molina de Aragón), 1.5.1932)

'Dear Mr. Navarro: A variety of circumstances have delayed considerably the despatch of our news. The distances between one place and another have proven to be great, and we have therefore had little time to write. Greetings to Vallelado and Aguilera, and you are always greatly appreciated/Aurelio Espinosa y L. Rodríguez' 
(20) [usted]

Sr. D. T. Navarro Tomás. Madrid./Muy distinguido señor mío:/El estado de salud de mi esposa ha mejorado mucho, pero el médico le ha ordenado un par de meses de absoluto reposo [...] Creo que a pesar de ello podría aprovechar el tiempo en beneficio de los trabajos del Atlas, si Vdes. me mandasen las primeras instrucciones [...] (Letter from F. de B. Moll to Tomás Navarro Tomás (Palma), 23.1.1934)

'T. Navarro Tomás, Esq. Madrid./My distinguished Sir:/My wife's health has improved greatly, but the doctor has prescribed her a couple of months of absolute rest [...] I think that she might, nonetheless, make use of the time to the advantage of the atlas, if you were to send me the initial set of instructions [...]'

(21) [usted]

Querido señor Castro: muchas gracias por su carta. De Rosenblat no sé nada; supongo que sigue en París, ya que lo del Ecuador, como usted le previno, es cosa más que problemática [...] (Letter from Luis Cernuda to Américo Castro (Surrey), 24.10.1938)

'Dear Mr. Castro: Many thanks for your letter. I have no news of Rosenblat; I presume he is still in Paris, since the Ecuador business is, as you anticipated, freighted with problems [...]'

In what amounts to a radical break from the previous generation, the younger institutionists show no variance in the forms they use. In the letters exchanged between friends and colleagues from their own generation, tuteo is reciprocal and systematic: $(\mathrm{T} \leftrightarrow \mathrm{T})$, as examples (22) to (24) illustrate.

(22) [tuteo]

Querido Federico:/Te escribo lleno de una gran serenidad y de tu santa calma; veras: ya hace un poco de mal tiempo en este bendito septiembre, llueve, hace viento, ancla un barco en el puerto [...] (Letter from Salvador Dalí to Federico García Lorca (Cadaqués), September 1926)

'Dear Federico:/I write to you full of great serenity and your own saintly calm: the weather is already a little rough this blessed September; it's wet and windy, a boat is dropping anchor in the harbour [...]'

(23) [tuteo]

Querido Sijé:/He quedado tristemente impresionado desde cuando recibí y leí tu carta: Dices que ahí no tienes más recursos. Pero tú debes intentarlo 
y porque tenga remedio. Madrid es cruel [...] (Letter from Miguel Hernández to Ramón Sijé (Madrid), 22.3.1932)

'Dear Sijé:/I have been all of a commotion since I received and read your letter: You say that you have run out of resources there. But you must make the attempt and find some remedy. Madrid is cruel [...]'

(24) $[$ tuteo $]$

Queridísimo Federico:/Con muchísima alegría, recibí, en Madrid, tu carta. Me la entregó Gustavo. No te he contestado antes por falta de tiempo./Hace tres días llegué aquí, a Rute. Ahora con toda tranquilidad te contesto [...] (Letter from Rafael Alberti to Federico García Lorca (Rute), 1.12.1925)

'Dearest Federico:/I was overjoyed to receive, in Madrid, your letter. Gustavo gave it to me. I haven't replied earlier for lack of time./I arrived here, Rute, three days ago. Now I am at complete leisure to answer you [...]'

Far from abrupt, this generational change from usted to the categorical use of tuteo was a gradual process. The seeds of social change had been sown in the second half of the 19th century and came to bear fruit among the generations born around the turn of the century, before finally spreading among the educated republican classes between 1920 and 1930 .

Testimony from the likes of Rafael Lapesa or his contemporaries Zamora Vicente and Dámaso Alonso is emphatic that it was during this period that a system of address in harmony with the progressive tendencies of the period caught on quite visibly in Madrid society. From the opening decades of the century until the outbreak of the Civil War in 1936, Madrid was the epicentre of a democratising sociolinguistic change which enjoyed the backing of university students, intellectuals, thinkers and artists who had been trained in republican ideals and converged in Madrid at a time of great social and political ferment.

\section{1930-1940: precipitation of social and linguistic change.}

Republican theoretical premises were the basis of a linguistic change which codified a new conception of personal relations. Freedom as an inalienable right, democracy as a system of government by the people, and the disappearance of the great social inequalities made up the republican scheme of things. Lapesa 
provides an eyewitness's explanation of the spread of tuteo on the coattails of new political tendencies:

Bien es verdad que la extensión del tú no es cosa de la última hornada, pues cundió en el decenio 1930-1940 con la camaradería reglamentaria en partidos políticos de diverso signo, y se afianzó con la sacudida de la guerra.

(Lapesa 1996a: 407)

'True enough, the spread of tú was not the work of the latest generation alone; rather it took root in the decade 1930-1940 and its regulatory camaraderie in political parties of diverse hues, and it was consolidated in the cataclysm of war.'

Social change found its reflection in a wholesale overhaul of customs that had traditionally served to underscore class difference: dress, language, manners and even headwear underwent substantial modifications. Lapesa (1996a: 363) recalls how in films of the period, the poets of the '27 generation doffed their hats in greeting until sinsombrerismo - the vogue for not wearing hats at all - "[e]mpezó entre la juventud y en el desahogo veraniego, pero cundió rápidamente según fueron llegando la amenaza y la efectividad de la guerra incivil". ${ }^{6}$ Sinsombrerismo signified the prosperous classes' renunciation of wearing hats, a fashion that had traditionally distinguished them from the lower classes.

When there are substantial changes in the political system, above all if they are of a revolutionary nature, the linguistic repercussions fail to penetrate into the structure of the language, although they may be reflected in the lexicon. ${ }^{7}$ During the Spanish Civil War (1936-1939), everything was in tumult and people's fates hung in the balance until the conclusion of the conflict. The cities like Madrid, Barcelona or Valencia that remained in the Republican zone were for a time under the spell of a classless society, which proved the ideal context for the spread of egalitarian forms of address. In such circumstances, the way people related to each other underwent drastic, albeit ephemeral, changes, which would not become consolidated once the totalitarian regime had been installed in Spain at the end of the war. These passing changes were commented upon by eyewitnesses to them. Passing through Barcelona, Orwell in Homage to Catalonia, which was first published in 1938, made express mention of the disappearance of formal expressions of address as well as of other aspects related to alterations to personal appearance and social behaviour as a result of the war:

6 'started among the young during carefree summers but gathered pace with the threat of the uncivil war and then the war itself'

7 Various studies have investigated in depth the change in nominal forms of address during this period. Cf. Fernández Lagunilla (1985) and García Santos (1980). 
Waiters and shop-walkers looked you in the face and treated you as an equal. Servile and even ceremonial forms of speech had temporarily disappeared. Nobody said Señor or Don or even Usted; everyone called everyone else comrade and Thou, and said Salud! instead of Buenos días [...] When I first reached Barcelona I had thought it a town where class distinctions and great differences of wealth hardly existed. Certainly that was what it looked like. Smart clothes were an abnormality, nobody cringed or took tips, waiters and flower-women and bootblacks looked you in the eye and called you comrade.

(Orwell 1938: 48; cf. Rodríguez González 1989: 236)

\section{Orwell perceived a similar state of affairs on the Aragon front:}

In the strip of Aragon controlled by Anarchist and P.O.U.M. ${ }^{8}$ troops, the same conditions persisted, at least outwardly. The revolutionary atmosphere remained as I had first known it. General and private, peasant and militiaman, still met as equals; everyone drew the same pay, wore the same clothes, ate the same food, and called everyone else thou and comrade; there was no boss-class, no menial-class, no beggars, no prostitutes, no boot-licking, no cap-touching. I was breathing the air of equality, and I was simple enough to imagine that it existed all over Spain.

(Orwell 1938: 103)

As for Zamora Vicente, his words paint a similar picture as he relates how in November 1936, four months after war was declared, the Republican Government had ordered the works of art housed in the Prado Museum to be removed to Valencia, where it too was to relocate, in order to protect them against bombardments. A photograph captured the moment the Meninas by Velázquez was carried out of the museum:

En esa imagen, aparecen las Meninas, tensas, sacadas de su refugio en las Torres de Serrano. Hay mucha gente en esa fotografía. A un lado, junto al cuadro, está Tomás Navarro [Tomás], serio, grave, encorbatado, clamoroso su traje frente a los monos de faena, los equipos seudomilitares, el visible calor del mediodía valenciano. Quizá es la única persona que, en ese momento, trata de usted a los soldados, obreros, carpinteros, funcionarios, curiosos... La foto corrió por todas partes. El contraste de Tomás Navarro con los demás retratados marcaba muy bien el paso del tiempo, el violento hiato que dividía nuestra sociedad.

(Zamora Vicente 1979: 426)

'The picture shows the Meninas, tense, removed from their refuge in the Torres de Serrano. There are many people in the photograph. To one side, next to the painting, is Tomás Navarro [Tomás], serious, grave, wearing a tie, his suit conspicuous amongst the workmen's overalls, the pseudo-military teams, the visible heat of Valencia at midday. He may be the only person who, at that moment, addresses the soldiers, workmen, carpenters, functionaries, bystanders as usted... The photo was circulated everywhere. The contrast between Tomás Navarro and the other people in the picture was eloquent of the passage of time, of the violent rupture that divided our society.'

8 Partido Obrero de Unificación Marxista ‘Workers’ Party of Marxist Unification’ 
But as fast as the changes had spread, so they were reversed months later as one defeat on the battlefield followed another:

The "revolutionary" forms of speech were dropping out of use. Strangers seldom addressed you as tú and camarada nowadays; it was usually señor and usted. Buenos días was beginning to replace salud.

(Orwell 1938: 48)

\subsection{Letters from the trenches}

The analysis of letters written from the front during the Civil War (1936-1939) is particularly fruitful when gauging the extent of tuteo popular. This corpus of letters corresponds in part to Republican soldiers writing from different fronts. The largest group of letters is from the Extremadura front, but other letter collections from the Avila, Ebro, Alicante and other fronts have also been examined. Where known, and frequently they are not, the origins of the soldiers are completely heterogeneous.

In addition to the letters written by Republican soldiers, we have also reviewed a corpus of letters written by Francoist troops to their madrinas de Guerra 'war godmothers', a practice that was widespread on the Francoist front as a means to keeping the combatants' morale high. The significance of this collection is twofold: on the one hand, it allows cross-checking to determine whether there were ideologically conditioned differences in the use of tuteo. On the other hand, it reflects address outside family relationships and in the sphere of communication between men and women who were at first unknown to each other, then became acquaintances and sometimes even friends, that is to say, in the sphere of egalitarian relations between people of the same generation. Examples (25) to (29) illustrate the letters from soldiers on the front.

(25) $[$ tuteo]

Nena, me dices en la tuya que no me enfade porque no me pongas besos ni abrazos en las cartas porque te da mucha vergüenza de poner eso en las cartas, pues te digo que a mí me gusta y quiero que me los pongas. (Miguel Romero to Pepa Lozano) ${ }^{9}$

9 Where some of the letters reproduced here were written and the relationship between sender and receiver are sometimes unknown. In each case we provide all available data. 
'Babe, in your letter you tell me not to be angry if you don't put kisses or hugs in your letters because you find it embarrassing to put them in your letters. But what I say is that I like it and I want you to put them.'

(26) [tuteo]

Luis, en esta carta yo tengo que contarte algo y es que ya no soy herrador, que no quiero ganar la guerra poniendo clavos, pues he venido otra vez a la trinchera como soldado [...] y de lo que me dices que no véis a las mujeres nada más que en los periódicos, pues yo te digo que yo al pueblo hace un mes que no bajo. (Efigenio Gallego to his friend Luis Martín, both from Don Benito (Badajoz), from the Extremadura front)

'Luis, I've got to tell you something in this letter, and the thing is I'm not a farrier, I don't want to win the war by hammering nails, but I'm back in the trenches as a soldier [...] and as for what you tell me about not seeing women except in the newspapers, for my part, I haven't been down to the village in more than a month.'

(27) [tuteo]

Juan, me dices que te cuente algo de la familia, pues no te puedo decir más que a mi hermana Paca no le pagan la pensión que le pertenece de su marido muerto en campaña, a mi Ángeles no le pagan la pensión perteneciente a la mía y a mí tampoco me pagan lo que me pertenece de mi accidente. (Antonio Vicente to his friend Juan Camacho Ferré, from the Avila front)

'Juan, you ask me to tell you something about the family, and all I can tell you is that they haven't paid my sister Paca the pension she's entitled to for her husband killed in action, they haven't paid my Angeles the pension she's entitled to for mine, and they haven't paid me what I'm entitled to for my accident.'

(28) [tuteo]

Pedro, sabrás cómo hemos estado unos días de jaleo pero a mí no me ha pasado nada; también te digo que quisiera que lo hubieras visto tú obuses donde estábamos nosotros, que nosotros estábamos a unos 200 o 300 metros y ya hubieras visto el tangai que se lio [...] (Emilio Quiles to Pedro Pardo (Granada), from the Avila front)

'Pedro, as you must know, we've had a few days of rumpus, but I'm all right; I can also tell you that I wish you'd seen the shells where we were, I mean, we were 200 or 300 metres away and you'd have seen the mess it all caused [...]' 
(29) [tuteo]

José en este momento silban los proyectiles facciosos y caen aquí en la huerta mía, fíjate si arrastraremos miedo. (Manolita Paredes to José Corner)

'José, right now the rebels' missiles are whistling and landing in my vegetable plot. Imagine how afraid we are.'

The first great difference between the 19th-century emigrants' letters and those written by soldiers on the front is the change in register that characterises the soldiers' writing, which does without traditional letter structure and adopts an often colloquial tone lacking all formality. Tuteo was the dominant mode of address among the Republican soldiers: of the 62 letters, 54 use tuteo, while the remaining eight, six of which are addressed to parents, employ usted. Using tuteo for friends of either sex and even for acquaintances was the norm among these soldiers, and it was often accompanied with terms of endearment and colloquial words. It is significant that occasionally, and always between men, bad language is used, as illustrated in examples (30) and (31). This anticipates the trend towards colloquialism across Spanish society as a whole in the latter decades of the 20th century.

(30) [tuteo]

[...] Sobre lo de la comida las estamos pasando más que putas, ya que en Intendencia cada vez van desquitando la ración de carne [...] (Letter from Juan Gri Rovira to Eduardo Valle (Mataró))

'As for the food we're going through hell, as the quartermasters are always taking the meat ration from us [...]'

(31) [tuteo]

también te digo que he recibido el pitillo que me has mandado pues por aquí jodíamente del tabaco, pues tú no sabes lo bien que me sentó cuando me lo estaba fumando, no hacía nada más que acordarme de $t i$ en que si fumabas. (Letter from Germán, on the Teruel front, to his nephew Virgilio)

'I can also tell you that I received the fag you sent me, because cigarettes are few and bloody far between here, and you can't imagine how good it felt when I smoked it, all I could do was think about you and whether you were smoking'

The collection of letters written by Francoist soldiers includes letters from 37 different authors addressed to the war godmothers. 31 of the letters reviewed were 
written during the Civil War (1936-1939) and a further six between 1941-1943, by Francoist soldiers serving with the Blue Division. ${ }^{10}$ These letters frequently commence or conclude with phrases like Arriba España, Arriba Franco or Viva la Falange 'Up with Spain!', 'Up with Franco!' or 'Long live the Phalange!', although it should be pointed out that camarada was used by communists and Phalangists alike, as can be seen in examples (32) to (36).

(32) [tuteo]

Queridos camaradas del PC, os mando un saludo revolucionario a todos en general. Me acuerdo de vosotros en el segundo aniversario de la guerra de España que han declarado unos generales traidores a la patria [...] (Comissaire Anselmo Ruiz to the members of UGT and PCE (Orellana la Vieja))

'Dear comrades of the C[ommunist] $\mathrm{P}$ [arty], I send you all a revolutionary salute. You are all in my thoughts on the second anniversary of the war in Spain, declared by a group of generals who have betrayed their country'

(33) [tuteo]

Camarada Delegada de la Sección Femenina de F.E.T. y de las J.O.N.S.”/ Distinguida camarada: No hay derecho a que por no ser uno andaluz se vea privado de tener una madrina sevillana./Tú bien sabes que en Navarra no falta el valor en los hombres, pero en cambio falta la sal en las mujeres [...] Espero no me negarás la gracia de tener una madrina sevillana, por lo que quedo a tu incondicional disposición con un fuerte "Arriba España”: Jesús Fortún (Letter from Jesús Fortún to his war godmother, 1938)

'Fellow Delegate of the Women's Section of the F.E.T. and the J.O.N.S.'1/ “Dear Comrade: It's not fair that just because someone isn't Andalusian he can't have a godmother from Seville./As you know, while men from Navarre are not lacking in courage, its women are short of spice [...] I trust you won't begrudge me a Sevillan godmother, and I, remaining entirely at your service, I greet you with a loud “Up with Spain!”: Jesús Fortún’

10 The Division Azul, or Blue Division, was the unit of the Spanish army which fought alongside Nazi troops during the Second World War.

11 F.E.T. and the J.O.N.S.: Falange Española Tradicionalista and the Juntas de Ofensiva Nacional Sindicalistas were two right-wing organisations which merged in 1934 and became known simply as the Phalange. 
(34) [tuteo]

Arriba España/Viva la Falange Femenina de Sevilla, ele./Maria La Laffite le escribe a mi amigo Vizcaino y le dice que si no tiene algún compañero que quiera Madrina de Guerra y yo inmediatamente acepté y a toda prisa me apresuro a comunicartelo, no sea que haya alguno que haya leido la carta y quiera anticiparseme porque entonces las bofetadas se van a oír en Campana [...] Supongo que me contestareis a toda velocidad para que digais el lugar de la cita mientras tanto me despido de tí con un fuerte./Arriba España/José Andrés (First letter from José Andrés to his war godmother, 13.8.1937)

'Up with Spain!/Long live the Women's Phalange of Seville, ele./Maria L ${ }^{\mathrm{a}}$ Laffite writes to her Biscayan friend she asks him if he doesn't know anyone who wants a War Godmother and I accepted at once and hurry to tell you in case someone else has read his letter and wants to beat me to it, in which case the thumping will ring out to high heaven [...] I suppose you'll answer me without delay to tell me where we meet. In the meantime I bid you farewell with a loud./Up with Spain'

(35) [tuteo]

¡Saludo a Franco! iiArriba España!!/Porcuna (Jaén) 22 marzo 1938/II Año Triunfal./Srta. Carmina Sánchez Sevilla/Simpatíca madrinita:/Hace ya una enormidad de tiempo que te escribí, enviandote al mismo tiempo una foto, y hasta la fecha no he tenido el gusto, ni el placer, ni el honor de recibir contestación, alguna, aunque solo hubiesen sido unas lineas. Tu silencio me demuestra que [...] Sin otro particular y pendiente de tús prontas y agradables? noticias, recibe un afectuoso Saludo nacional-Sindicalista de tu ahijado,/José Romera (First letter from José Romera to his war godmother)

'Hail Franco! Up with Spain!!/Porcuna (Jaén) March 22th, 1938/II Triumphal Year./Miss. Carmina Sánchez Sevilla/Dear little godmother:/I wrote to you an absolute age ago, enclosing a photo too, and up till now I haven't had the privilege, the pleasure or the honour to receive any reply, not even just a few lines. Your silence shows me that [...] Looking forward to your prompt and pleasant? news, please accept a warm National-Syndicalist greeting from your godson,/José Romera'

(36) [tuteo]

¡Ea! Ya tienes un ahijado mujer, y un ahijado como tu lo querías. Has tenido la suerte que tus deseos encajaran perfectamente en mi fisico [...] ;Viva La Muerte!/¡Viva La Legión! (First letter from Víctor to his war godmother, 19.1.1939) 
'Blow me! Now you've got a godson, lady, and a godson just as you wanted. It's your good luck that your wishes fit my physique perfectly [...] Long live death!/Long live the Legion!'

In the letters to war godmothers, tuteo is the most habitual form address used. The only difference is whether tuteo commences with the first letter, when both interlocutors are still completely unknown to each other, or from the second, when an agreement has been reached to start an epistolary relationship. of the 37 soldiers comprising this part of the corpus, 29 (79\%) start using tuteo from the very first letter despite not knowing their potential war godmother; in contrast, only 8 (21\%) employ usted in their first letter, as in examples (37) and (38).

(37) [usted $]$

Apreciable Srta:/Mucho le agradezco que se haya dignado escogerme por ahijado, máxime teniendo en cuenta que mi nombre no es de los que atraen o hacen propaganda por si mismo [...] (First letter from Ramón Vega to his war godmother (Madrid), 1937)

'Dear miss:/I'm very grateful that you've been good enough to choose me to be your godson, above all bearing in mind that my name isn't the most attractive or the best advertisement [...]'

(38) [tuteo]

Estimada madrinita:/Hoy he recibido tu simpática carta [...] (Second letter from Ramón Vega to his war godmother)

'Dear little godmother:/Today I received your kind letter [...]'

Thus soldiers on both sides not only shared a new paradigm of pronominal address, but also similar dreams of equality, which were also countenanced in the ideology of the Spanish Phalange, ${ }^{12}$ expressed in example (39).

(39) [tuteo]

Simpática madrinita:/Aunque la lectura de tu carta ha sido un poco accidentada debido a que la mitad la he tenido que suspender para echarle una bronca al Furriel de la compañía, después cuando la he leido por segunda

12 Traditionalist Spanish Phalanx of the Committees of the National Syndicalist Offensive (FET and the JONS). 
vez, la he asimilado y me ha alegrado mucho. Lo de tratarme de tu, lejos de enfadarme me ha gustado mucho, soy falangista hasta la médula y me honra el que en España se vaya generalizando la costumbre de tratarnos familiarmente que nuestro querido "Ausente" deseaba [...] (Letter from José Lardiés Bosque to his war godmother. (Zaragoza), aged 22, 1938)

'Dear little godmother:/Although I had to interrupt my reading of your letter halfway through in order to give a ticking off to the company's quartermaster sergeant, afterwards, when I read it a second time, I was able to take it all in and it made me very happy. As for addressing me as tu, far from making me angry, it made me feel pleased as I'm a Phalangist to the marrow and proud of the fact that the custom of addressing each other in this familiar way is becoming widespread, much as our dear "Absent One"13 wished [...]'

Although the corpus of letters studied does not provide sufficient data for any categorical assertion, there seems to be a relationship between level of education and use of tuteo, for the soldiers who employed usted in their first letter were usually those who had received the least education. One extreme case of a barely educated letter writer is Manuel Fernández Barbosa, who adopts usted and whose multiple spelling mistakes impede any easy reading (example (40)).

\section{(40) [usted]}

Miqueridisima Madrina es taes para decirle que oi dia 1 e caido en san lucar con mucho dis gusto poravel me venido y no avel la visto y ave y do que es ta talde pensava de aver y do alla a los pita [...] (Letter from Manuel Fernández Barbosa to his war godmother)

'My dearest godmother, this is to tell you that today I've been in Sanlucar and am so upset for coming and for going without seeing you that this afternoon I thought I could have gone to the hospital [...]'

Another is Fernando Giménez Fernández, barely literate like Manuel Fernández who writes only two letters and in both uses usted (example (41)).

13 José Antonio Primo de Rivera, founder of the Phalange in 1934 and executed in Alicante in November 1936. 
(41) [usted]

Distingida Señorita:/Sunonbre ast haora pormi des conocido, ha llegaohastami trinchera Enel montos en qe la nostagia por la ausencia de to da mifamilia, esmenos lle vadera [...] (Letter from Fernando Giménez Fernández to his war godmother)

'Esteemed miss:/Your name, till now unknown to me, has reached me in my trench at a time when my I'm finding it hardest to take missing all my family [...]'

Table 4 sums up the usage of tú and usted in the Republican and Francoist soldiers' letters.

\subsection{Letters from prison}

The last groups of letters analysed were written by republican prisoners, male and female, in Francoist prisons. These are mainly authorised letters exchanged between the prisoners and their families, although there are also some clandestine notes written in highly colloquial, lower class language, often with spelling mistakes, since this group of letters is characterised by the low educational level of their writers. ${ }^{14}$ Table 5 gives a summary of tú and usted use in this set of letters.

Among the prisoners, tuteo is almost completely consolidated. Of the 33 letters produced by different writers, 32 employ tuteo against only one, addressed to a mother, using usted (examples (42) and (43)).

[tuteo]

Maruja, ves a ver a Engracia, vive en Artista 7, es familia de Carmen Barrero, di que está bien y poneros de acuerdo vosotros, nosotras hacemos la vida juntas. No os digo más por no poder. Dar muchos recuerdos a todos de mi parte y recibir un fuerte abrazo y un millón de besos de vuestra hija y hermana. Dionisia (Dionisia Manzanero, aged 20, (Madrilenian district of $\mathrm{Cu}$ atro Caminos), member of $\mathrm{PCE}^{15}$, one of the thirteen roses).

14 Prison correspondence also included the so-called letters of supplication written by the inmates of Francoist prisons from a position of subordination to the authorities responsible for their imprisonment and therefore not quantified in our study. In these letters usted is the only form of address used within a rigid formal structure where the nominal address is V.S. (Vuestra Señoría).

15 PCE: Spanish Communist Party. 


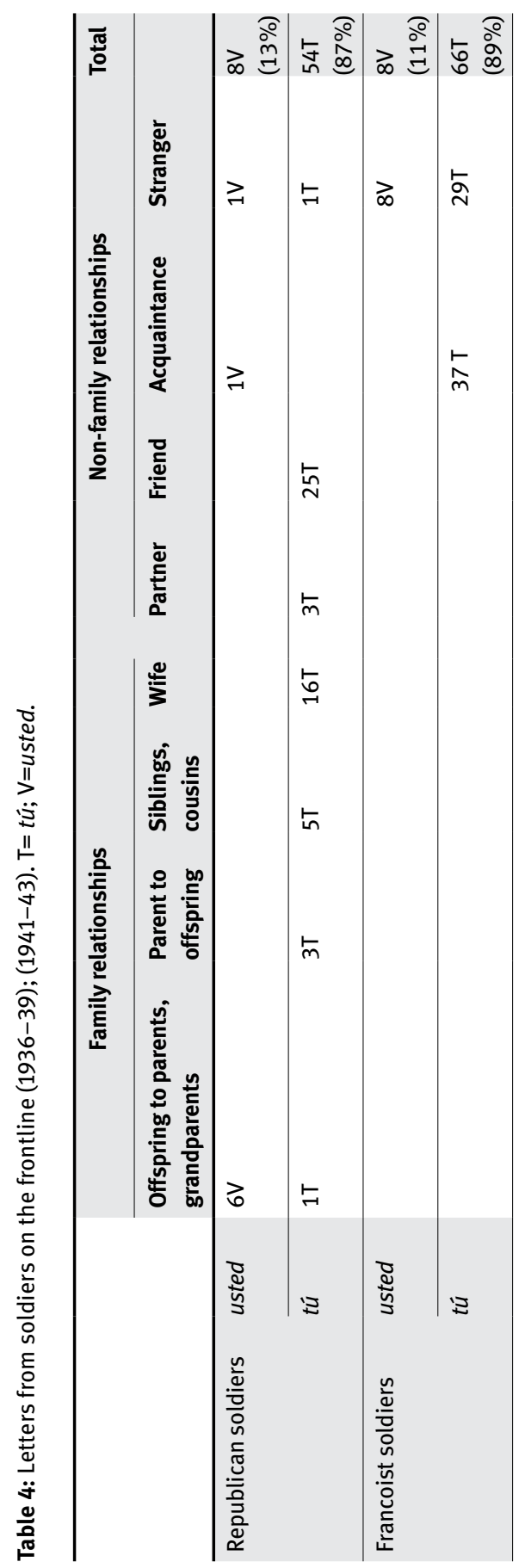


Table 5: Letters from Republican prisoners in Francoist prisons (1939-1945). T=tú; V=usted.

\begin{tabular}{|c|c|c|c|c|c|c|c|}
\hline & \multicolumn{4}{|c|}{ Family relationships } & \multicolumn{2}{|c|}{ Non-family relationships } & \multirow[t]{2}{*}{ Total } \\
\hline & $\begin{array}{l}\text { Offspring } \\
\text { to parents, } \\
\text { grandparents }\end{array}$ & $\begin{array}{l}\text { Parents to } \\
\text { offspring }\end{array}$ & $\begin{array}{l}\text { Siblings/ } \\
\text { cousins }\end{array}$ & Wife & Partners & Friends & \\
\hline usted & $1 \mathrm{~V}$ & & & & & & $1 \mathrm{~V}$ \\
\hline tú & $3 \mathrm{~T}$ & $2 \mathrm{~T}$ & $3 \mathrm{~T}$ & 7T & $4 \mathrm{~T}$ & $13 \mathrm{~T}$ & $32 \mathrm{~T}$ \\
\hline
\end{tabular}

'Maruja, pop in on Engracia, calle Artista 7, relative of Carmen Barrero, and tell her it's all right and come to an agreement. We're getting on with life together. I can't tell you more. Pass on my Greetings to everyone and a big hug and a million kisses from your daughter and sister. Dionisia'

(43) [tuteo]

Mamá, el día 1 vienes con la madre de Loli. Darás muchos recuerdos a mis hermanos y sobrinos y a todos, y tú recibes lo que quieras de $t u$ Juli, que no te olvida. Julia". "Mamá, ánimo y no llores, que tú has sido siempre muy fuerte, y no te vayas a poner mala". (Julia Conesa Conesa, aged 19 (Madrid), member of $\mathrm{JSU}^{16}$, one of the thirteen roses).

'Mama, come the 1st with Loli's mother. Please give my regards to my brothers, sisters and cousins, and to everybody, and for you, everything you could wish from your Julie, who never forgets you. Julia". "Mama, cheer up and don't cry, after all you've always been very strong, and you're not going to make yourself ill now".'

In the clandestine notes, where the level of colloquialism and informality is greater, tuteo is once again the norm, as illustrated in examples (44) to (47).

(44) [tuteo]

Las niñas están bien corriendo por lacalle [sic] pina es mui [sic] simpatica el dia que medieron [sic] las tarjetas me dice trai [sic] mana yo yo telas [sic] leo y me acen [sic] gracia que dicen UHp saluz camarada y alcan [sic] el puño que eslarisa [sic] con ellas. (Prisión del Dueso (Santoña, Santander), note written by the wife of prisoner José Peña Quintanal)

16 JSU: Unified Socialist Youth. 
'The girls are well, dashing about the street. Pina's very nice. The day they gave me the cards, she says give them to me, mum, and I'll read them for you, and it's funny when they say UHp Hail comrade and raise their fists - it makes you laugh.'

(45) [tuteo]

Querido hijo emos [sic] recibido la tarjeta y por ella beemos [sic] que disfrutas de saluz [sic] nosotros todos buenos/Sin mas por hoy recibes muchos recuerdos de toda la familia de tus hermanos y de estos tus Padres que de corazon te quieren, Julia y Vicente.

'Dear son, we got your card and we see that you're well; we all are too./ That's all for today. Greetings from all the family, from your brothers and sisters and from these parents of yours who love you with all their heart, Julia and Vicente.'

(46) [tuteo]

Jose tu carta tenia que haber benido [sic] el Jueves y a llegado oy [sic] Sabado, figurate que dos dias mas penosos y tristes para mi [...]

'Jose, your letter should have arrived on Thursday but it came today, Saturday. Just imagine what a few sad and painful days I've had [...]'

(47) [tuteo]

Me dices lo mucho que sufres moralmente por mi y nuestra separacion tan larga y asi Paco mio sucede en mi, que es un continuo pensar y sufrir con el recuerdo constante de cuanto tu sufres y una separacion que se me hace inmensa $[. .$.

'You tell me how much you're suffering for me in your soul on account of our endless separation, and the same happens to me, Paco. I'm endlessly thinking and suffering at the constant recollection of how much you're suffering and this being apart which is overwhelming me'

\section{Conclusion: the development of a linguistic change in the social structure}

The letters studied have enabled us to reconstruct the socio-political context which facilitated the rise of tuteo in Spain around the turn of the century, to trace 
its spread through Spain's social fabric of the time and, in sociolinguistic terms, to determine which interests common to the different social sectors led to the development of an egalitarian system of pronoun use.

In the last few decades of the 19th century and the first decades of the 20th, testimony from diverse sources demonstrates how tuteo in Spanish society began to spread beyond the family sphere and into relations between friends and acquaintances of either sex. The correspondence of the Galician and Asturian emigrants to America shows how from at least the second half of the 19th century the use of tuteo among the lower and fledgling middle classes had spread beyond family circles. Nonetheless, the shift towards tú for non-family relationships occurred before its consolidation as the term of address used for parents. The coexistence of tuteo for friends with usted for parents leads to the conclusion that in social terms relationships with friends were perceived as closer than those with parents, in relation to whom traditional hierarchies were preserved for much longer.

Once the linguistic change was set in train, its spread was simultaneously from below and from above. In the same period the new usage was propagated among society's lower classes (tuteo popular) and in the higher echelons (upper class tuteo) which had witnessed the evolution since the 19th century of egalitarian, non-hierarchical relationships with interlocutors from the same social group.

All this occurred at a time of far-reaching social, political, economic and cultural transformations which found expression in the growth of workers' organisations and the flowering of the institutionist spirit among leading sectors of the political class. The innovation was able to triumph because new actors emerged in the social fabric whose interests converged: the lower class, the new urban middle classes, and the cultural and political elites all shared an urge to modernise which found an outlet in the reformist project of the Second Republic. University students took up tuteo popular which was by then already widespread among the lower classes, whose interests were shared by the republican bourgeoisie. But that common ground was shared not only by the different social groups but also by ideological opponents, since both Phalangist doctrine and left-wing ideology advocated a political project of popular appeal which favoured an egalitarian conception of social relations. When intellectuals aligned themselves with the change from below in the early decades of the 20th century, the writing was on the wall for the 19th-century system of address.

This innovative development can be given, so to speak, names and surnames since it was the second generation of institutionists who gave the definitive push from above to a change which was being spread from below by the lower classes. Although this scenarios might imply an abrupt change, the process was in fact gradual. The seeds of social change which had been planted in the second half 
of the 19th century came to fruition among the generations born around the turn of the century and were propagated among the educated republican classes between 1920 and 1930; their correspondence is plain testimony to the abrupt consolidation of the change in its final stages.

During the Civil War, the markedly colloquial letters written by members of the lower classes show the fully consolidated use of tuteo in relationships between peers. In none of the letters written from the frontline or the prisons are friends addressed as usted. On the contrary, there is a marked tendency towards the "bad" language that was to impregnate everyday language in the second half of the 20th century.

Although the end of the war represented a turning point in the development of Spanish society, the letter collections show that there was no retreat in the use of tuteo, which in fact survived unchanged in egalitarian intragroup relations among the new generations born around the turn of the century. It may well be that this huge impulse given to the system of pronouns in the early 20th century is part of the explanation for today's differences between the Spanish system of address and its equivalents in Spanish-speaking America.

\section{References}

\section{Epistolaries}

Altolaguirre, Manuel. 2005. Epistolario 1925-1959. Madrid: Residencia de Estudiantes.

Anderson, Andrew A. \& Christopher Maurer (eds.). 1997. Federico García Lorca. Epistolario completo. Madrid: Cátedra.

Castillejo, David. 1999. Epistolario de José Castillejo. 3 vols. Madrid: Castalia.

Castillo, Antonio \& Feliciano Montero (eds.). 2003. Franquismo y memoria popular. Madrid: Siete Mares.

Castillo, Antonio \& Verónica Sierra (eds.). 2014. Cinco siglos de cartas. Historia y prácticas epistolares en las épocas moderna y contemporánea. Huelva: Universidad de Huelva Publicaciones.

Cortés Carreres, Santi \& Vicent García Perales. 2009. La historia interna del Atlas Lingüístico de la Península Ibérica (ALPI). Correspondencia (1910-1976). València: Universitat de València.

Fonseca, Carlos. 2014. Trece rosas rojas y la rosa 14. Madrid: Temas de hoy. Hinojosa Durán, José. 2009. Tropas en un frente olvidado. El ejército republicano en Extremadura durante la Guerra Civil, 316-344. Mérida: Editora Regional de Extremadura. López Álvarez, Juaco. 2000. Cartas desde América. La emigración de asturianos a través de la correspondencia. 1864-1925. Revista de Dialectología y Tradiciones Populares 55,1. 81-120. 
Martínez Aguirre, Rebeca. 2014. La escritura de cartas en las cárceles de mujeres durante el franquismo. In Antonio Castillo \& Verónica Sierra (eds.), 391-410.

Martínez Martín, Laura. 2010. “Asturias que perdimos, no nos pierdas". Cartas de emigrantes asturianos en América (1863-1936). Gijón: Muséu del Pueblu d’Asturies.

Matthews, James. 2015. Voces de la trinchera. Cartas de combatientes republicanos en la guerra civil española. Madrid: Alianza.

Menéndez y Pelayo, Marcelino \& Leopoldo Alas Clarín. 1943. Epistolario. Prólogo de G. Marañón. Madrid: Ediciones Escorial.

Ramón, Manuel de \& Carmen Ortiz. 2003. Madrina de guerra. Cartas desde el frente. Madrid: La Esfera de los Libros.

Sierra Blas, Verónica. 2003. Al otro lado de las rejas. Correspondencia a los presos del Centro Penitenciario de El Dueso (Santander, 1936). In Antonio Castillo Gómez \& Feliciano Montero García (eds.), 55-97. Madrid: Siete Mares.

Sierra Blas, Verónica. 2005. En espera de su bondad, comprensión y piedad. Cartas de súplica en los centros de reclusión de la guerra y posguerra españolas (1936-1945). In Antonio Castillo \& Verónica Sierra (eds.), Letra bajo sospecha, 165-200. Gijón: Ediciones Trea.

Sierra Blas, Verónica. 2008. Palabras en la nieve. Una carta desde el frente de Aragón. El Filandar. O Fiadeiro 18. 12-15.

Soutelo Vázquez, Raúl. 2003. La correspondencia de los emigrantes gallegos. In Antonio Castillo Gómez \& Feliciano Montero García (eds.), Franquismo y memoria popular. Escrituras, voces y representaciones, 123-176. Madrid: Siete Mares.

\section{References to linguistic and social studies}

Alba de Diego, Vidal \& Jesús Sánchez Lobato. 1980. Tratamiento y juventud en la lengua hablada. Aspectos sociolingüísticos. Boletín de la Real Academia Española 60, 219. 95-129.

Alonso, Dámaso. 1962. La muerte del usted. In idem, Del siglo de oro a este siglo de siglas, 264-267. Madrid: Gredos.

Beascoechea Gangoiti, José María \& Luis Enrique Otero Carvajal (eds.). 2015. Las nuevas clases medias urbanas. Transformación y cambio social en España, 1900-1936. Madrid: Catarata.

Bustos Gisbert, Eugenio \& Silvia Iglesias Recuero. 2003. Relaciones familiares y formas de tratamiento en la novela realista del siglo XIX. In José Luis Girón Alconchel et al. (eds.), Estudios ofrecidos al profesor José J. de Bustos Tovar, vol. 1, 277-295, Madrid: Servicio de publicaciones de la Universidad Complutense.

Calderón Campos, Miguel. 2010. Los elementos nominales en el sistema de tratamientos del español de Andalucía durante la Restauración (1875-1931). Historia y situación actual de los pronombres de tratamiento en el español peninsular. In Hummel et al. (eds.), 531-549.

Fernández Lagunilla, Marina. 1985. Aportación al estudio semántico del léxico político: el vocabulario de los republicanos. Hamburg: Helmut Buske.

Fox, Jeremy. 1969. The pronouns of address in Spanish. In Alexandru Graur (ed.), Actes $d u$ $X^{e}$ Congrès International des Linguistes (Bucarest 28 août-2 Septembre 1967), vol. 1, 685-693. Bucharest: Académie de la République Socialiste de Roumanie.

García Godoy, María Teresa. 2008. La reconstrucción del sistema de tratamientos en el español de Andalucía (s. XIX). In Esteban Montoro del Arco, María A. López Vallejo, Francisco José 
Sánchez García (eds.), Nuevas perspectivas en torno a la diacronía lingüística. Actas del VI Congreso Nacional de la Asociación de Jóvenes Investigadores de Historiografía e Historia de la Lengua Española (Granada, 29-31 de marzo de 2006), 31-65. Granada: Servicio de Publicaciones de la Universidad de Granada.

García Godoy, María Teresa. 2010. El tratamiento a los progenitores en el español peninsular (siglo XIX). Contraste de dos variedades geográficas. Historia y situación actual de los pronombres de tratamiento en el español peninsular. In Hummel et al. (eds.), 595-617.

García Santos, Juan E. 1980. Léxico y política de la segunda República. Salamanca: Universidad de Salamanca.

Hummel, Martin, Bettina Kluge \& María Eugenia Vázquez Laslop (eds.). Formas y fórmulas de tratamiento en el mundo hispánico. México DF/Graz: El Colegio de México/Karl-FranzensUniversität Graz.

Lapesa, Rafael. 1996a. Nuestra lengua en la España de 1898 a 1936. In idem, El español moderno y contemporáneo. Estudios lingüísticos, 343-396. Barcelona: Crítica Grijalbo Mondadori.

Lapesa, Rafael. 1996b. La lengua entre 1923 y 1963. In idem, El español moderno y contemporáneo. Estudios lingüísticos, 397-413. Barcelona: Crítica Grijalbo Mondadori.

Moreno Luzón, Javier \& Fernando Martínez López. 2012. La Institución Libre de Enseñanza y Francisco Giner de los Ríos: nuevas perspectivas, 3 vols. Madrid: Fundación Francisco Giner de los Ríos/Acción Cultural Española.

Otero Carvajal, Luis Enrique. 2014. La edad de plata y la renovación de la universidad española. In idem (ed.), La universidad nacionalcatólica. La reacción antimoderna, 15-67. Madrid: Universidad Carlos III.

Otero Carvajal, Luis Enrique. 2015. La sociedad urbana en España, vanguardia de la modernidad, 1900-1936. In José María Beascoechea \& Luis Enrique Otero (eds), Las nuevas clases medias urbanas. Transformación y cambio social en España, 1900-1936, 15-38. Madrid: Catarata.

Rodríguez González, Félix. 1989. Sociolingüística del tratamiento político: a propósito de Orwell. Revista de Estudios Políticos (Nueva Época) 63. 233-249.

Zamora Vicente, Alonso. 1979. Necrológica. Tomás Navarro Tomás, por su último discípulo en España. Boletín de la Real Academia Española 59,218. 413-431. 